\title{
Observational methodology in football: Development of an instrument to study the offensive game in football
}

\author{
H. Sarmento ${ }^{1}$, J. Leitão ${ }^{1}$, T. Anguera ${ }^{2}$, J. Campaniço ${ }^{1}$
}

1 - Universidade de Trás-os-Montes e Alto Douro, Portugal

2 - Universidad de Barcelona, Spain

\begin{abstract}
The following paper introduces a new approach to the analysis of offensive game in football. Therefore, the main aim of this study was to create an instrument for collecting information for the analysis of offensive action and interactions game. The observation instrument that was used to accomplish the main objective of this work consists of a combination of format fields (FC) and systems of categories (SC). This methodology is a particular strategy of the scientific method that has as an objective to analyse the perceptible behaviour that occurs in habitual contexts, allowing them to be formally recorded and quantified and using an ad hoc instrument in order to obtain a behaviour systematic registration that, since they have been transformed in quantitative data with the necessary reliability and validity determined level, will allow analysis of the relations between these behaviours. The codifications undertaken to date in various games of football have shown that it serves the purposes for which it was developed, allowing more research into the offensive game methods in football.
\end{abstract}

Key words: observational methodology, offensive game, football.

The most striking change within football's development is the application of science to its problems and in particular the use of increasingly sophisticated technology that, supported by scientific data, allows us to establish a "code of reading" of the reality of the game (Castelo, 2004).

Traditionally, the publications in the analysis of the game are mostly confined by the collection of quantitative indicators (e.g., number of passes), qualitative indicators (e.g., areas recovering from ball), and external indicators (e.g., distance) of the game. However, these indicators cannot necessarily capture the full complexity of a performance when framed within the context that has led to its expression (Borrie, Jonsson \& Magnusson, 2002); specifically through an interactive analysis of contextual factors within the actions of the game, since their identity is created through an articulation of the system which creates conditions to maintain or change, depending on the circumstances (Garganta, 2005).

The different variables inherent to competition, the interaction that occurs between them and the difficulty in controlling the contextual variables, never the same in different situations, demand the use of observational methodology (Mendo, Anguera \& Santos, 2005). In our study, maintaining that variability is an inherent aspect to each game and that significant behaviors show an emerging trend during game events, we propose to 
determine behaviors, spatial and contextualized variables that allow to characterize and distinguish the offensive game methods a Soccer match.

The aim of this paper is to describe the development of an instrument for observation that can strengthen the existing schemes of game analysis in football in order to provide specific additional information on the offensive game methods.

\section{Methods}

Since the observation allows us to objectively describe reality in order to analyze it, the definition of the objectives becomes compulsory.

They were: a) identify indicators of technical and tactical performance and ascertain the existence of differences due to: i) different specific game cultures (Premier League, Italian League and Portuguese League), ii ) location of the game (home / away); iii) game time (periods of 15 minutes), and iv) momentary result of the marker (lose / draw / win); b) characterize the tactical performance of counter-attack, quick attack and positional attack of three teams with different cultures of game (English, Italian and Portuguese League), within a qualitative framework.

After the objectives had been defined, we prepared the monitoring system. This is a combination of field formats and category systems, which had been developed ad hoc. The use of field formats provides the instrument with dimensionality and flexibility, and makes it readily adaptable, whereas the category systems render it more consistent. The observational design in our study, based on the specific characteristics of the subject dimensions, and time and flow, is of Follow-up design /Nomothetic/ multidimensional (F/N/M).

In order to prepare the field format, we firstly defined the instrument's vertebrates criteria and then, through an exploratory phase, produced an opened list of behaviors / situations observed, corresponding to each criterion. This exploratory phase was carried through the observation of video images for games $(n=9)$ of the English, Italian and Portuguese Leagues, focusing on the offensive sequences observed in those games. The games were recorded on VHS video and then converted to MPEG-1.

As done in previous studies (e.g., Lopes, 2007; Silva, 2004), the process of development of our observational tool started by setting criteria. For each of the criteria dimensions (according to the field formats), we built a system of categories for subsequent data collection based on diachronic settings.

\section{Results}

Ten criteria were defined through observation of relevant conduct in every offensive sequence: 


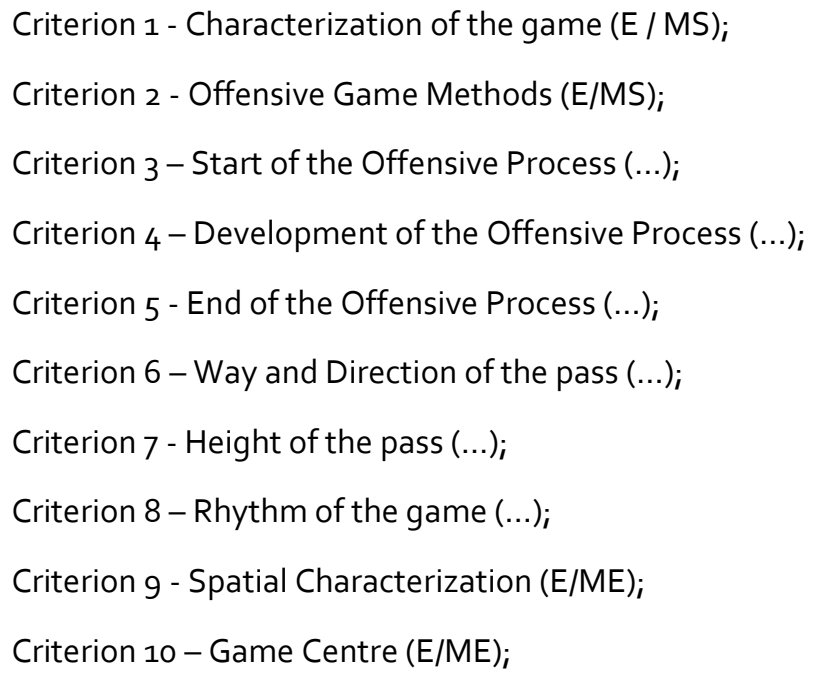

The criteria were produced by a system of comprehensive and mutually excluding categories (criteria one, two, nine and ten). Of these, six (three to eight criteria) have an open character. This construction converged in a system in which all behaviors were likely to be registered, so that to each corresponds only one category.

The next phase was the allocation of a set of behaviors that correspond to each of the criteria, forming a list called the catalog.

In Tables 1 and 2 it is presented an example of the conduct attributed to the six criteria, way and direction of the pass:

Table 1. Settings for the criterion 6.

\section{Field Format Criteria 6}

Way and direction of the pass (TP)

Conceptual Definition: Represents the direction of the ball during their movement between two elements of the same team with the aim of following up the game to allow the continued and successful possession of the ball.

We propose 3 possible categories to guide the actions techniques - Way / Direction.

\begin{tabular}{ccc}
\hline Categories & Code & Description \\
\hline Pass to the front & PPf & $\begin{array}{c}\text { Where the holder of the ball makes a pass } \\
\text { towards the opponent goal. }\end{array}$ \\
Pass to the back & PPt & $\begin{array}{c}\text { Where the holder of the ball makes a pass } \\
\text { towards the defended goal. }\end{array}$ \\
Pass to the side & PPI & $\begin{array}{l}\text { Where the holder of the ball makes a lateral } \\
\text { pass to the axis of attack. }\end{array}$ \\
& $\ldots$ & $\ldots$ \\
\hline
\end{tabular}


Table 2. General structure of the Instrument (part 1)

\begin{tabular}{|c|c|c|c|c|}
\hline $\begin{array}{c}\text { Criterion } \\
1\end{array}$ & $\begin{array}{c}\text { Criterion } \\
2\end{array}$ & $\begin{array}{c}\text { Criterion } \\
3\end{array}$ & $\begin{array}{c}\text { Criterion } \\
4\end{array}$ & $\begin{array}{c}\text { Criterion } \\
5\end{array}$ \\
\hline $\begin{array}{c}\text { Characterization } \\
\text { of the game }\end{array}$ & $\begin{array}{l}\text { Method of } \\
\text { Offensive Play }\end{array}$ & $\begin{array}{c}\text { Start of the } \\
\text { Offensive } \\
\text { Process }\end{array}$ & $\begin{array}{c}\text { Development } \\
\text { of the } \\
\text { Offensive } \\
\text { Process }\end{array}$ & $\begin{array}{c}\text { Ending of the } \\
\text { Offensive } \\
\text { Process }\end{array}$ \\
\hline $\begin{array}{l}\text { Portuguese L. } \\
\text { English L. } \\
\text { Italian L. } \\
\text { Part } 1 \\
\text { Part } 2 \\
\text { Home } \\
\text { Away } \\
\text { Wins + } 1 \text { goal } \\
\text { Wins } 1 \text { goal } \\
\text { Draw } \\
\text { Loses } 1 \text { goal } \\
\text { Loses + } 1 \text { goal }\end{array}$ & Quick attack & $\begin{array}{c}\text { Recovery of } \\
\text { possession of } \\
\text { ball by } \\
\text { interception } \\
\text { Recovery of } \\
\text { possession of } \\
\text { ball for } \\
\text { disarmament } \\
\text { Recovery of } \\
\text { possession of } \\
\text { ball } \\
\text { by action of the } \\
\text { goalkeeper } \\
\text { recovery of } \\
\text { possession of } \\
\text { ball by } \\
\text { interruption to } \\
\text { regulate } \\
\text { Recovery of } \\
\text { possession of } \\
\text { ball } \\
\text { by the goal } \\
\text { opponent }\end{array}$ & $\begin{array}{c}\text { Dev. by passing } \\
\text { short / medium } \\
\text { Dev. by passing } \\
\text { over } \\
\text { Dev. by } \\
\text { conduction } \\
\text { Dev. by } \\
\text { reception / } \\
\text { control } \\
\text { Dev. by dribble } \\
\text { (1x1) } \\
\text { Dev. by duel } \\
\text { Dev. by action } \\
\text { of the } \\
\text { goalkeeper of } \\
\text { the team in } \\
\text { offensive phase } \\
\text { Dev. by shot } \\
\text { Dev. by } \\
\text { crossing } \\
\text { Development } \\
\text { with assistance } \\
\text { from the } \\
\text { unsuccessful } \\
\text { opponent } \\
\text { Development } \\
\text { of action with } \\
\text { Goalkeepers of } \\
\text { the opposing } \\
\text { team }\end{array}$ & $\begin{array}{c}\text { With } \\
\text { Effectiveness } \\
\text { Shot to obtain } \\
\text { goal } \\
\text { Shot within } \\
\text { shot defended } \\
\text { by GK } \\
\text { Shot out } \\
\text { Shot against } \\
\text { opponent } \\
\text { Direct free kick } \\
\text { Corner } \\
\text { Penalty } \\
\text { Pass into the } \\
\text { large area } \\
\text { opponent } \\
\text { Not } \\
\text { Effectiveness } \\
\text { Recovery of } \\
\text { possession of } \\
\text { ball by the } \\
\text { opponent } \\
\text { all out } \\
\text { Infringement of } \\
\text { gams of the } \\
\text { game }\end{array}$ \\
\hline
\end{tabular}


Table 2. General structure of the Instrument (part 2)

\begin{tabular}{|c|c|c|c|c|}
\hline $\begin{array}{c}\text { Criterion } \\
6\end{array}$ & $\begin{array}{c}\text { Criterion } \\
7\end{array}$ & $\begin{array}{c}\text { Criterion } \\
8\end{array}$ & $\begin{array}{c}\text { Criterion } \\
9\end{array}$ & $\begin{array}{c}\text { Criterion } \\
10\end{array}$ \\
\hline $\begin{array}{c}\text { Way and } \\
\text { Direction of the } \\
\text { pass }\end{array}$ & $\begin{array}{l}\text { Height of the } \\
\text { pass }\end{array}$ & $\begin{array}{l}\text { Rhythm of the } \\
\text { game }\end{array}$ & $\begin{array}{l}\text { Spatial } \\
\text { Characte- } \\
\text { rization }\end{array}$ & Game Centre \\
\hline \multirow{12}{*}{$\begin{array}{l}\text { Pass to the } \\
\text { Front } \\
\text { Pass to the back } \\
\text { Pass to the side }\end{array}$} & \multirow{12}{*}{$\begin{array}{c}\text { Shallow Pass } \\
\text { Half time Pass } \\
\text { High Pass }\end{array}$} & Fast rhythm & 1 & PRESSURE \\
\hline & & \multirow{11}{*}{$\begin{array}{l}\text { Slow / medium } \\
\text { rhythm }\end{array}$} & 2 & Relative inferiority \\
\hline & & & 3 & Absolute inferiority \\
\hline & & & 4 & Equal pressure \\
\hline & & & 5 & \\
\hline & & & 6 & NO PRESSURE \\
\hline & & & 7 & Equality not pressed \\
\hline & & & 8 & Relative Superiority \\
\hline & & & 9 & Absolute superiority \\
\hline & & & 10 & \\
\hline & & & 11 & \\
\hline & & & 12 & \\
\hline
\end{tabular}

\section{Conclusion}

The codifications undertaken to date in various games of football, using this instrument, have shown that it serves the purposes for which it was developed, allowing more research into the offensive game methods in football. Also, it enables the analysis of aspects of the game through perspective and contextual sequences, which we consider to more accurately fit the "reality" of the game of football.

Since these types of studies require stability within observations, i.e., the existence of reliability in data collection, it is essential to assure for data quality, which can be verified by the degree of inter-observer agreement (Kappa index of reliability).

\section{References}

Borrie, A., Jonsson, G., \& Magnusson, M. (2002). Temporal pattern analysis and its applicability in sport: An explanation and exemplar data. Journal of Sports Sciences, 20(10), 845-852.

Castelo, J. (2004). Futebol - organização dinâmica do jogo. Lisboa: FMH-UTL. 
Garganta, J. (2005). Dos constrangimentos da acção à liberdade de (inter) acção, para um Futebol com pés... e cabeça. In D. Araújo (Ed.), O contexto da decisão - A acção táctica no desporto (pp. 179-19o). Lisboa: Visão e Contextos, Lda.

Lopes, J. (2007). Análise diacrónica heterocontingente dos métodos de jogo ofensivo no futebol: Estudo em equipas de nível competitivo superior. Tese de Mestrado não publicada, Porto: Faculdade de Desporto.

Mendo, G., Anguera, T., \& Santos, R. (2005). Desarrollo y optimización d euna herramienta observacional en el tenis de individuales. Psicothema, 17(1), 123-127.

Silva, A. (2004). Padrões de jogo no processo ofensivo em Futebol de Alto rendimento: Análise dos jogos da segunda fase do Campeonato do Mundo Coreia-Japão 2002. Tese de Mestrado não publicada, Madrid: Universidad Autónoma de Madrid. 